\title{
MULTIVARIATE INFORMATION DYNAMIC MONITORING SYSTEM APPLICATION OF TUNNEL CONSTRUCTION PROCESS MODEL TEST
}

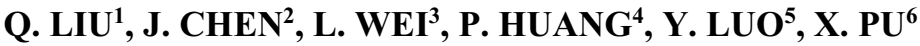

\begin{abstract}
Geomechnical model testing has been widely applied as a kind of research technique in underground engineering problems. However, during the practical application process, due to the influence of many factors, the desired results cannot be obtained. In order to solve this problem, based on the measurement requirements of the model test, combined with FBG(Fiber Bragg Grating) sensor technology and traditional measurement methods, an FBG monitoring system, Micro-multi-point displacement test system, resistance strain test system and surrounding rock pressure monitoring system are developed. Applying the systems to a model test of the tunnel construction process, the displacement in advance laws of tunnel face, radial displacement distribution laws and surrounding rock pressure laws are obtained. Test results show that a multivariate information monitoring system has the advantage of high precision, stability and strong anti-jamming capability. It lays a solid foundation for the real-time data monitoring of the tunnel construction process model test.
\end{abstract}

Keywords: tunnel engineering, model test, multivariate information, dynamic monitoring

\footnotetext{
${ }^{1}$ Lecture, School of Civil Engineering, Chang'an University, Xi'an, Shanxi 710061, China, e-mail:1q0719@163.com

2 Professor, School of Highway, Chang'an University, Xi'an, 710064, China, e-mail:chenjx1969@163.com

3 Post-Graduate, School of Civil Engineering, Chang'an University, Xi'an, Shanxi 710061, China, e-mail:632407411@qq.com

${ }^{4}$ Lecture, School of Civil Engineering, Chang'an University, Xi'an, Shanxi 710061, China, email:297357506@qq.com

5 Associate professor, School of Highway, Chang'an University, Xi’an, 710064, China, e-mail: 412986428@qq.com

${ }^{6}$ Post-Graduate, School of Highway, Chang'an University, Xi'an, 710064, China, e-mail: 1028782436@qq.com
} 


\section{INTRODUCTION}

The geomechanical model testing method is an effective method to study large-scale geotechnical problems $[1,2]$, which is comprised of using similar materials indoors, making similar models in accordance with similar principles $[3,4]$, and is based on observations of stress, strain and displacement of multivariate information to understand the mechanical phenomenon and the law of stress and displacement field on the prototype in order to achieve the goal of guiding geotechnical engineering design and construction. During the construction of soft and fractured surrounding rock tunnels, the deformation after excavation can be divided into three types: advance displacement in front of the tunnel face, displacement of the tunnel face, and rear displacement of tunnel face. These three types of displacements occur simultaneously during construction. Due to practical, advanced displacement in front of the tunnel face and displacement of the tunnel face itself, measurements are difficult to obtain by means of monitoring. We can conduct effective analysis and discussion of weak/broken surrounding rock by using a similar geomechanical model test method. However, model tests are influenced by many factors [5-8] in the actual application process, making it difficult to achieve the desired effect. Among them, the multi-information acquisition technology of dynamic monitoring of the testing process has become an important factor, restricting the development of geomechanical model testing. As we know, the multi-information of geomechanical model test includes stress, strain, pressure and displacement etc. Common measurement methods include mechanical and electrical measuring methods [7]. In addition, optical sensing technology has been widely used in recent years [9-15]. Researchers carried out a lot of research in monitoring technologies of model tests and achieved many research results. ZHU Wei-Shen [16] designed and manufactured a high-precision multi-point extensometer in the underground cavern stability model test in Shuangjiangkou Hydropower Station, and gained the cavern's displacement variation laws throughout the whole process of excavation. ZHANG Qiang-yong [17] got stress and displacement variation laws in Hurongxi Large Tunnel Expressway model tests by using a mechanical micro-multipoint extensometer, and he revealed the surrounding rock damage mechanism of bifurcation tunnel. Zhang Qing-song [18] applied a typical flow-solid, coupling similar materials and a similar simulation test, and obtained the variation laws of seepage and temperature field resulting from the surrounding rock deformation and the change of the seepage boundary condition. The multiinformation during the tunnel construction process, such as dynamic monitoring of the first displacement, the displacement and rear displacement of tunnel face is rarely studied. However, the 
successful capture of multi-information during tunnel construction is the key to the success of the model test.

Therefore, in order to explore the dynamic multi-information monitoring system during the tunnel construction process, capture the displacement field and stress field, and improve the accuracy of measurements, and there is no doubt as to the full play of advantages of model test technology. Based on the grating optical fiber monitoring technique, a diverse collection of information for the monitoring system is built as the core of the optical fiber parallel real-time dynamic monitoring system. Combined with high-precision mechanical and grating type micro-displacement meter and other means, according to the model test measurement requirements, a multi-information monitoring system was devised and successfully used in the tunnel construction process. Model test results show that the system can be used to monitor the tunnel construction process multi-information, and it can capture small changes and fluctuation values of multi-unit messages, and it laid the foundation for the success of the model test.

\section{TUNNEL CONSTRUCTION PROCESS MODEL TEST}

\subsection{TEST SURVEY}

This test was based on the mass deformation of typical broken surrounding rock at Gui-Guang Line TianPing mountain tunnel. DK372+335 DK372+435 section was chosen for simulating the geological mechanics model test, The average depth of the section was 380 meters. The simulative size of the prototype was: width (vertical to the tunnel axis direction, namely the $\mathrm{X}$ axis) $\times$ height (along the elevation direction, namely $\mathrm{Y}$ axis) $\times$ thickness (parallel to the tunnel axis, namely $\mathrm{Z}$ axis) $=120 \mathrm{~m} \times 120 \mathrm{~m} \times 100 \mathrm{~m}$. The geometric similar size ratio of the geological model test is 1:50 according to the work outline. From here the simulative size of the model was obtained: width (is vertical to the tunnel axis direction, namely the $\mathrm{X}$ axis) $\times$ height (along the elevation direction, namely $\mathrm{Y}$ axis) $\times$ thickness (is parallel to the tunnel axis, namely $\mathrm{Z}$ axis) $=2.4 \mathrm{~m} \times 2.4 \mathrm{~m} \times 2 \mathrm{~m}$. Similar material was used with cementation of metal ferrous grains (IBSCM) [19]. It is made of iron ore powder, barites powder, sand, gypsum powder, rosin, alcohol according to the regulation ratio through uniform mixing and compaction. Iron ore powder, barites powder and sand are the main materials The solution of rosin and alcohol is glue and gypsum powder is regulation. The research object was weak and broken surrounding rock and the modified gypsum powder is a brittle material. So, in the 
process of material selection, the gypsum powder ratio was $0 \%$. The model loading system used the hydraulic loading system to carry on the inhomogeneous step load.

\subsection{MONITORING PROGRAM}

Relying on the actual situation of the construction method, this model test used two step excavation methods and excavated at the opposite direction of the tunnel. It explains the transformation law of the internal stress field and displacement field in the surrounding rock and the change in the construction process by the monitoring point of displacement, stress and strain.

The model test was set with 4 strain monitoring sections (a-d), 4 primary displacement monitoring sections (A-D), 3 secondary displacement monitoring sections ( I-III), 5 extrusion displacement monitoring sections (1-5) and 2 surrounding rock pressure monitoring sections $(\alpha, \beta)$. There were 18 sections and 198 monitoring points in total. The monitoring section is shown in Figure 1.

\begin{tabular}{|c|c|c|c|c|c|c|c|c|c|c|c|}
\hline & & & & & & & & & & & \\
\end{tabular}

Fig. 1. Monitor section position sketch

Section A, B, C and D in the figure were the primary displacement monitoring sections. The optical fiber displacement sensor was fixed at the hole at $0.5,1,2$ and 3 times the diameter of the hole on the wall in the primary displacement monitoring sections. The section I, II and III were the lesser displacement monitoring sections which were used for measuring the antecedent displacement in front of the tunnel face during excavation. The mechanical multi point displacement tools developed independently were arranged at section one, two, three, four and five to measure the vertical extrusion displacement of the section during excavation.

After excavating, the deformation can be divided into: the antecedent displacement in front of tunnel face, the displacement of tunnel face and the displacement behind tunnel face. These three kinds of displacement will appear at the same time in the tunneling process. Therefore, the purpose 
of all kinds of supporting measures in the process of tunnel construction is restraining the development of these three kinds of displacement, and also restraining surrounding rock relaxation caused by these displacements. Therefore, it has important practical significance to study the conditions and development laws of these three kinds of displacement and to take appropriate measures to control displacement for the design and construction periods.

The position of monitoring points were set up around the hole densely, according to the rule that points should be set up at the integer times of the tunnel diameter on the tunnel rock:

There were 70 displacement monitoring devices, including 52 optical fiber displacement sensors and 18 multipoint displacement tools;

There were 100 strain monitoring machines, including 14 optical fiber strain gauges, 22 bidirectional electric strain gauges and 64 one-way resistance strain gauges.

28 micro pressure boxes were set up.

The monitoring points were arranged as shown in Figure 2:

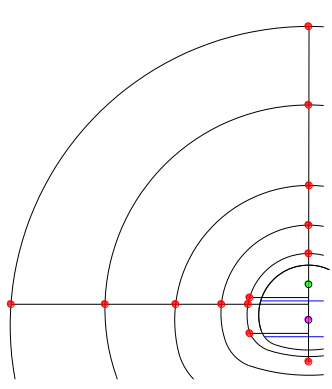

displacement monitoring elements layout

fiber optic displacement sensor multi-displacement-monitoring instrument (extrusive+vertical)

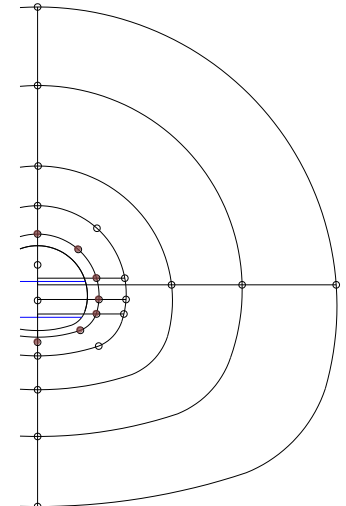

strain monitoring elements lay ou

unidirectional strain gauge multi-displacement-monitoring instrument (extrusive)

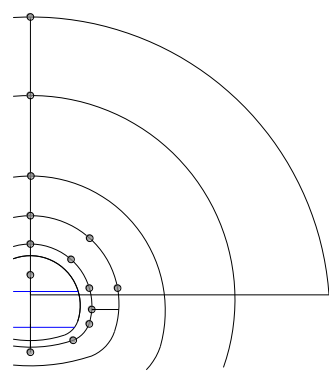

earth pressure cell layout

two-way strain gauge(extrusive+vertical) earth pressure cell

Fig. 2. Monitoring points position sketch 


\subsection{TEST PROCESS}

A three dimensional model was made by using the method of tamp filling. It was loading in the first, and then excavating at this test. The self-weight stress in the vertical direction and the tectonic stress in the horizontal direction were considered. Then the horizontal tectonic stress acted as: $\sigma_{x}=\sigma_{z}=\lambda \sigma_{y}$, and the lateral pressure coefficient is 0.75 according to the actual situation and experience.

The average depth of the tunnel was $380 \mathrm{~m}$, so the depth of the model was $7.6 \mathrm{~m}$ as calculated by the similarity ratio. The distance from the tunnel vault to the top of the model was $1.045 \mathrm{~m}$, and the surface of the model needed to be applied with the material self-weight stress of the model in $6.555 \mathrm{~m}$. The horizontal tectonic stress should also be applied on the basis of the lateral pressure coefficient.

The model was divided into four parts, and each part of the length is $50 \mathrm{~m}$. The east entrance of tunnel was taken as the starting mileage $(0 \mathrm{~m})$. The excavation was carried out in the east of the model within $100 \mathrm{~m}$ firstly, and then the west of the model within $100 \mathrm{~m}$. The two-step bottom excavation method was used at $0-50 \mathrm{~cm}$, and then anchor and shotcrete support was taken after excavation. The two-step bottom excavation method was also used at $50-100 \mathrm{~m}$, but shotcrete was used without an anchor.

The two-step bottom excavation method was used at $200-150 \mathrm{~m}$ section, and an anchor and shotcrete support was taken after excavation. The two-step bottom excavation method was used at $150-100 \mathrm{~m}$ section, but only shotcrete was used. The length of the upper bench and lower bench are both $10 \mathrm{~m}$, and supporting lag for a constructiong cycle. This test was carried out on both sides of the model and the excavation was distributed in the axial symmetry, due to consideration of the influence of different rock formations on the tunnel. The inclined packing is used in the process of filling in the model. The attitude of rock in this model is $90^{\circ} \angle 30^{\circ}$, and the tendency of rock is $90^{\circ}$ from north to east. It is excavated on the opposite direction of rock tendency in the east and on the same direction of rock tendency in the west. The similarities and differences of the mechanical effect law in the process of tunnel construction under these two conditions were researched. 


\section{DEVELOPMENT OF MULTIVARIATE INFORMATION}

\section{MONITORING SYSTEM}

\subsection{ARTICULATING FIBER SCOPES}

Based on the technology of wavelength division multiplexing and F-P cavity demodulation, the fiber Bragg grating sensor network is optimized and the fiber stress, displacement and other wavelength modulation type non light source is designed, which has the advantages of compact size, high accuracy, large range and high survival rate. At the same time, through the establishment of the calculation program of mass data processing, the data acquisition, analysis and early warning of multi information is realized. The performance index of each sensor is shown in table 1.

Table 1. The performance parameters of FBG sensors

\begin{tabular}{|c|c|c|}
\hline Performance index & Fiber optic strain sensor & Fiber optic displacement sensor \\
\hline Range & $-5000 \mu \varepsilon \sim+5000 \mu \varepsilon$ & $-10 \mathrm{~mm} \sim+20 \mathrm{~mm}$ \\
\hline Resolution & $\pm 1 \mu \varepsilon$ & $\pm 1 \mu m$ \\
\hline Measurement error & $<3 \mu \varepsilon$ & $<5 \mu m$ \\
\hline Interface mode & Standard FC interface & Standard FC interface \\
\hline Appearance and size & $30 \times 30 \times 30 \mathrm{~mm}$ & $\varphi 6 \times 60 \mathrm{~mm}$ \\
\hline
\end{tabular}

FBG strain sensor and FBG displacement sensor are connected by a coupler, and a local area optical network is formed by using wavelength division multiplexing technology. The optical signal is transmitted to the fiber grating demodulation system sm-125 with the measured physical quantity. In the model, the fiber grating sensor is transmitted through the signal transmission fiber, the sensing fiber is connected to the fiber coupler, and the input end of the fiber coupler is connected with the grating demodulation device directly. So, the optical fiber sensor network is composed of a complete optical fiber sensing network. The optical signal is converted into electrical signal by the optical signal, and then the data is automatically collected by the software system. The physical quantities and the curve can be observed directly on the computer. The model test of the optical fiber monitoring system is shown in Figure 3, Figure 4 and Figure 5. 


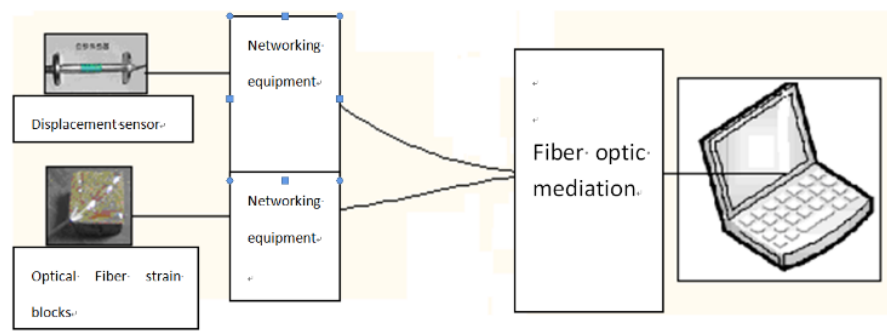

Fig. 3. FBG monitoring system diagram

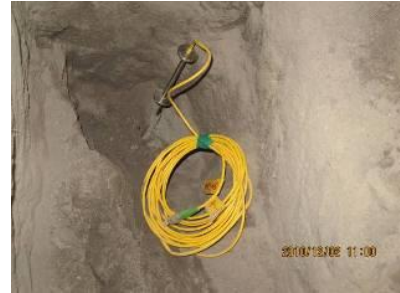

(a)Displacement sensor

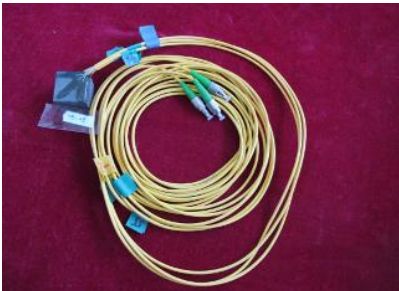

(b)Optical Fiber strain blocks

Fig. 4. FBG monitoring components
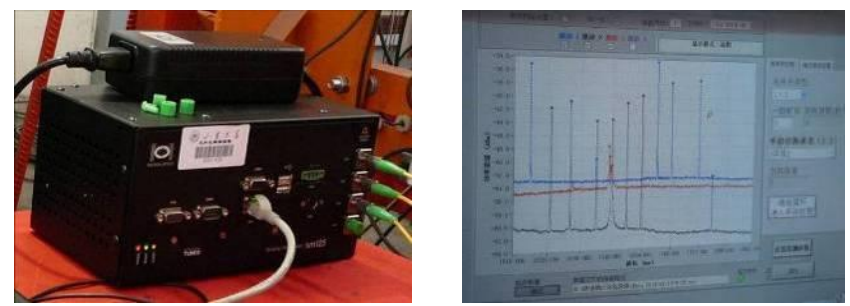

Fig. 5. FBG monitoring system

\subsection{MICRO MULTI POINT DISPLACEMENT METER TESTING SYSTEM}

Displacement is one of the most direct and accurate measurements of the stability of surrounding rock. In addition to fiber Bragg grating displacement sensors, we developed a mechanical and grating type micro-multi-point high-precision displacement measurement system, the accuracy of which can achieve $1 \mu \mathrm{m}$. Among them, the former is through an external digital display TESA dial gauge to get the displacement information inside the rock mass. Relative displacement by electron in dial gauge converter is used to realize full digital automatic real-time acquisition with a maximum range of up 
to $\pm 30 \mathrm{~mm}$, specifically shown in Figure 6 and Figure 7. The latter is done by Moire fringe measurement to show a grating pair of main grating (grating ruler) and a grating pair (indicating grating). Range depends on the type of grating ruler.

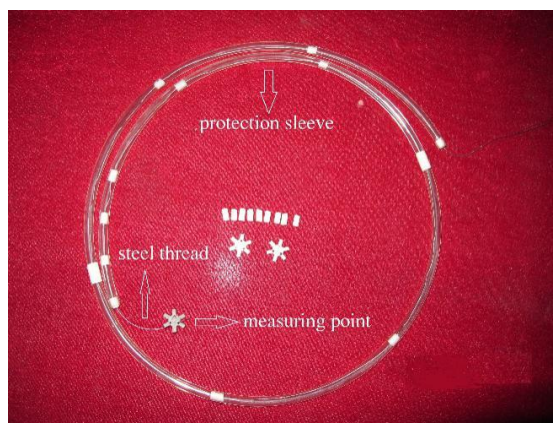

Fig. 6. Micro-multi-point displacement measurement points

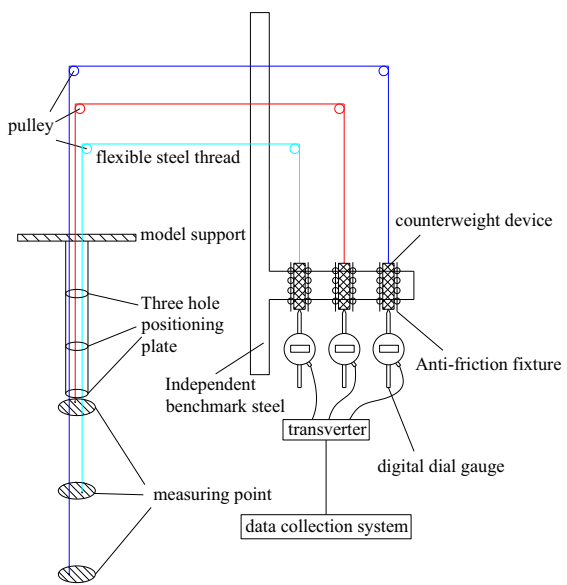

Fig. 7. Schematic diagram for working principle of mechanical multi-point extensometer
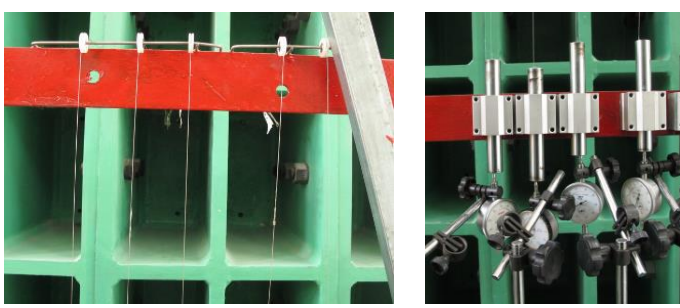

Fig. 8. Mechanical micro-multi-point displacement meter after installation 

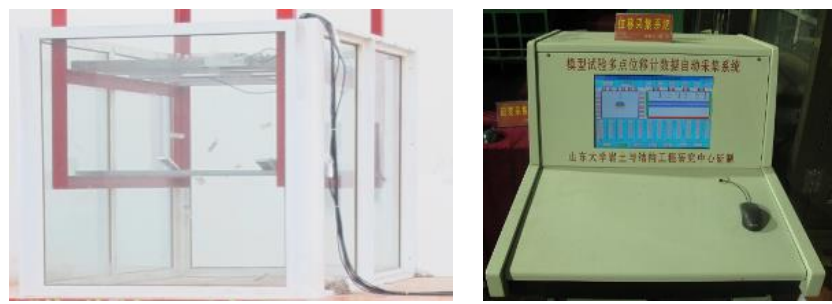

Fig. 9. Grating multi-point displacement meter data acquisition system

\subsection{RESISTANCE STRAIN AND SURROUNDING ROCK PRESSURE MONITORING SYSTEM}

Strain is measured by using resistance strain gauges within the tunnel; surrounding rock pressure test is measured by Micro - precision pressure box, diameter size of $16 \mathrm{~cm}, 7 \mathrm{~mm}$ height of the cylinder. Two kinds of strain acquisition system are adopted: XL2101G high speed static strain gauge and DH3816 static strain testing system. The software is composed of a static strain gauge, a computer and software. The XL2101G high-speed static strain gauge measuring system has the advantages of high accuracy, stable performance, strong anti-interference ability and small zero $\operatorname{drift}( \pm 3 \mu \varepsilon / 4$ hours ; $\pm 1 \mu \varepsilon /{ }^{\circ} \mathrm{C}$ ), automatic scanning balance, fast scan speed (1200 bit/sec). DH3816 strain testing system has high sensitivity, low drift, inspection, sampling, and other advantages, and it can be used in full bridge, half - and quarter bridge (public compensation) with multi point strain measurement and multi point pressure, force, temperature and other static physical test, and it is the most advanced strain acquisition and analysis system during the same period of domestic $[5,6,11,16,17,18]$. Figure 10 shows photos of the two high-speed static strain gauge test system. 
The micro pressure box embedding process is shown in figure 10 .

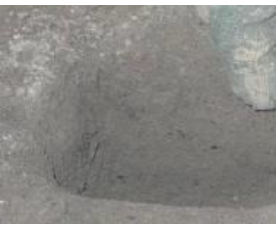

(a) Compression surface leveling

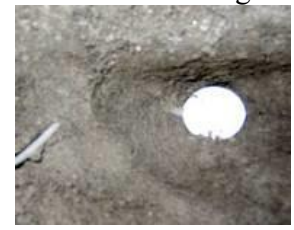

(d)Backfill material

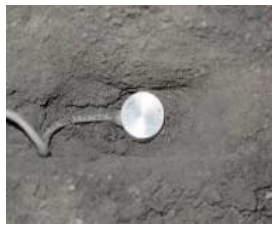

(b) Pressure box

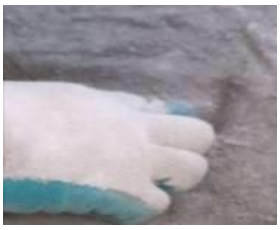

(e)Flat top coating material

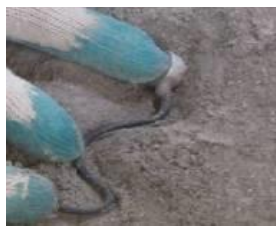

(c)Serpentine layout conductor

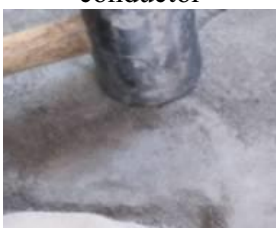

(f)Solid surface material

Fig. 10. Embedment procedure of micro earth pressure cell
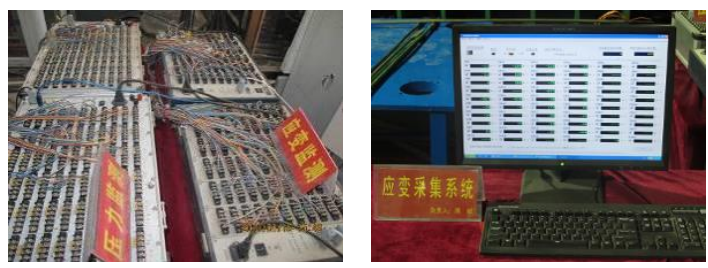

Fig. 11. Strain and pressure test system

\section{ANALYSIS OF TEST RESULTS}

\subsection{ANTECEDENT DISPLACEMENT VARIATION OF TUNNEL FACE}

During the process of tunnel construction, when the excavation of the upper bench working face was carried on to monitor section I and II, the vertical displacement value of each displacement monitoring section is shown in figure 12 . 


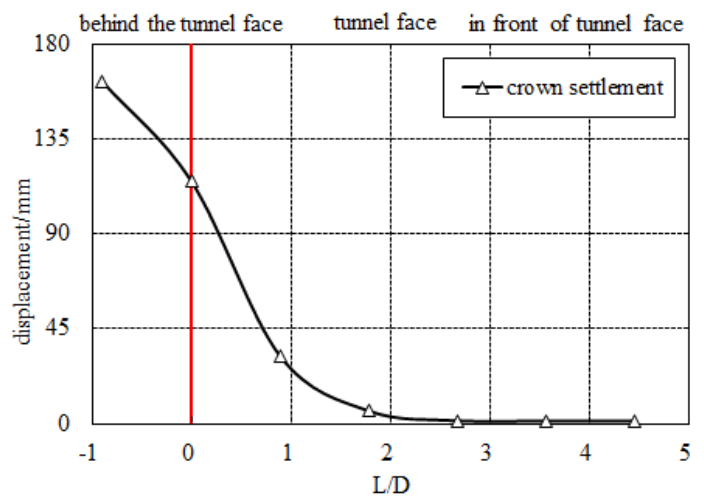

(a)The excavation of upper bench working face was carried on to monitoring section I

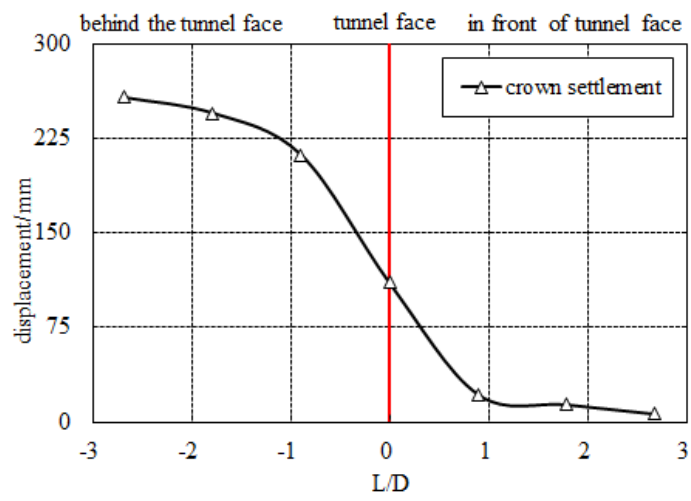

(b)The excavation of upper bench working face was carried on to monitoring section II

Fig. 12. Antecedent displacement variation of tunnel face

Tips: L-distance between monitoring section and working face, unit: $\mathrm{m}$, D-diameter of tunnel, unit: $\mathrm{m}$.

The figure shows that vault crown settlement takes places within the scope of the working face when the excavation of upper bench working face was carried on to monitor the section shown in the figure. Some instantaneous initial displacement took place just above the working face. The average value was about $110 \mathrm{~mm}$ which was about $40 \%$ of the final displacement value. Antecedent displacement took place within the scope of the diameter of the tunnel in front of the working face. 


\subsection{DISTRIBUTION OF TUNNEL RADIAL DISPLACEMENT}

Figure 13 shows the final radial displacement distribution of the four main monitoring sections. The final displacement values of each monitoring point are shown in table 2.

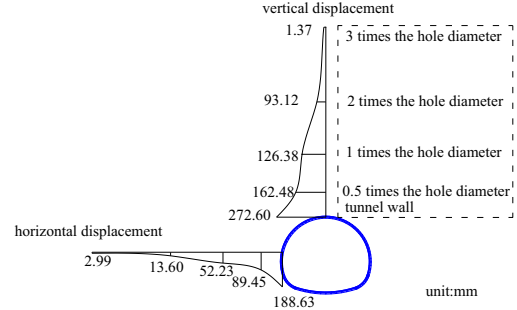

(a)final radial displacement distribution of section $\mathrm{A}$ vertical displacement

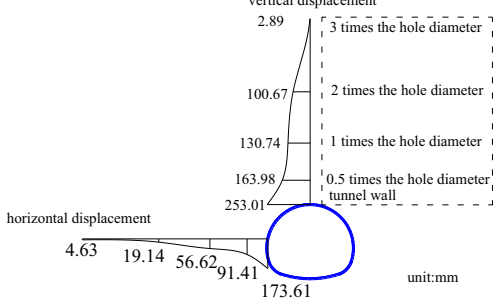

(c)final radial displacement distribution of section $\mathrm{C}$

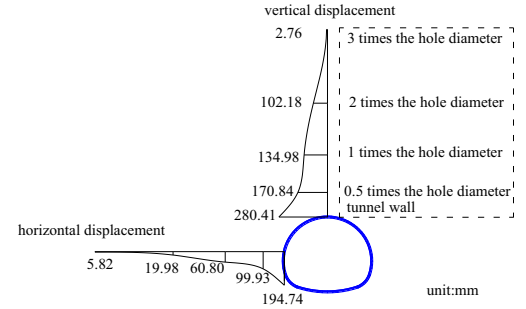

(b)final radial displacement distribution of section $\mathrm{B}$

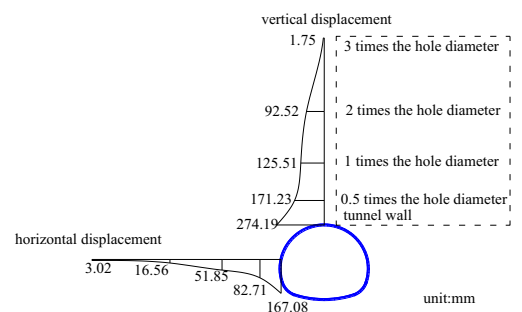

(d)final radial displacement distribution of section $D$

Fig. 13. Final radial displacement distribution of the monitoring sections

Table 2. Final peripheral displacement of the main monitoring sections

\begin{tabular}{ccccccc}
\hline & $\begin{array}{c}\text { Monitoring section } \\
\text { displacement }\end{array}$ & Tunnel wall & $\begin{array}{c}0.5 \text { tunnel } \\
\text { diameters }\end{array}$ & $\begin{array}{c}1 \\
\text { tunnel diameters }\end{array}$ & $\begin{array}{c}2 \\
\text { tunnel diameters }\end{array}$ & $\begin{array}{c}3 \\
\text { tunnel } \\
\text { diameters }\end{array}$ \\
\hline \multirow{2}{*}{ A } & level convergence & 194.63 & 99.93 & 60.80 & 19.98 & 5.82 \\
& crown settlement & 280.41 & 170.84 & 134.98 & 102.18 & 2.76 \\
\multirow{2}{*}{ B } & level convergence & 198.63 & 101.45 & 62.23 & 20.60 & 2.99 \\
& crown settlement & 282.60 & 172.48 & 136.38 & 103.12 & 2.37 \\
C & level convergence & 173.61 & 91.41 & 56.62 & 19.14 & 4.63 \\
& crown settlement & 253.01 & 163.98 & 130.74 & 100.67 & 2.89 \\
D & level convergence & 167.08 & 82.71 & 51.85 & 16.56 & 3.02 \\
& crown settlement & 274.19 & 171.23 & 125.51 & 92.52 & 1.75 \\
\hline
\end{tabular}

It is seen from the above chart that under this test condition, the scope of the surrounding radial displacement is less than three times the tunnel diameter on each tunnel monitoring section after excavation. For monitoring sections $\mathrm{A}$ and $\mathrm{B}$, the final displacement of section $\mathrm{B}$ is a little bigger than section A. This is due to the anchor of section A. It can clearly be seen that the anchor plays a role in displacement. Section $\mathrm{C}$ and $\mathrm{D}$ are the same. 


\subsection{VARIATION OF SURROUNDING ROCK PRESSURE}

During the test, the surrounding pressure variation of each test point is shown in figure 14

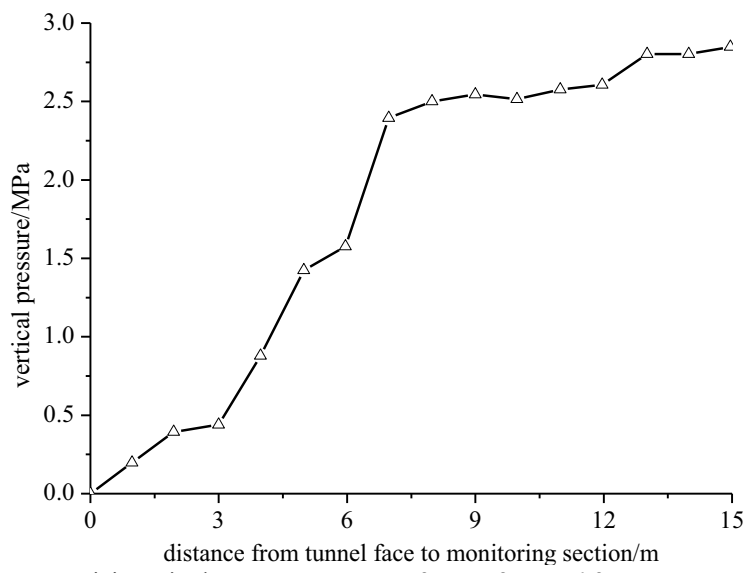

(a) Vertical pressure curve in front of tunnel face o

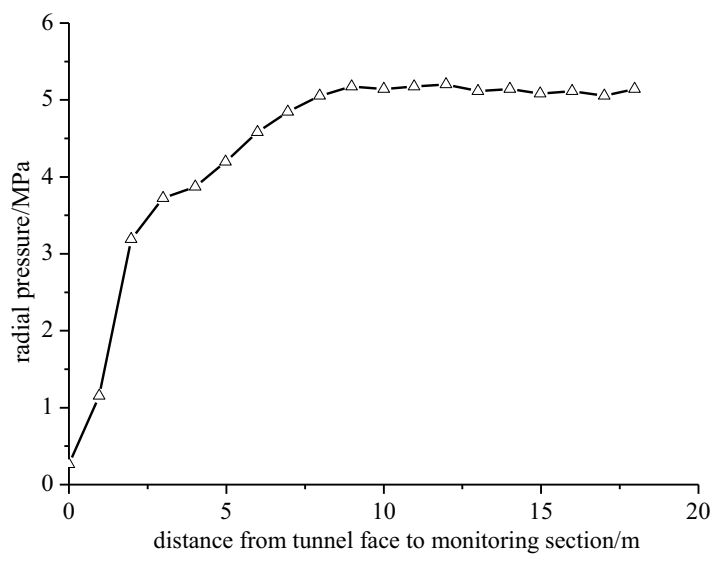

(b) Radial pressure curve of tunnel crown 


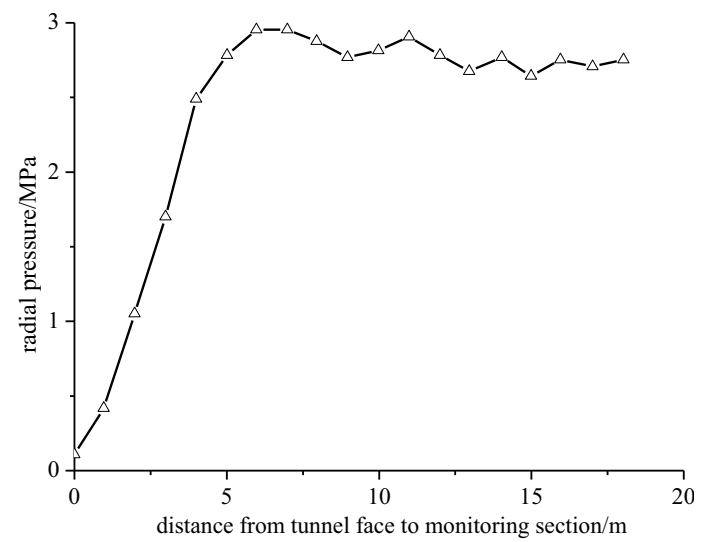

(c) Radial pressure curve of tunnel side wall

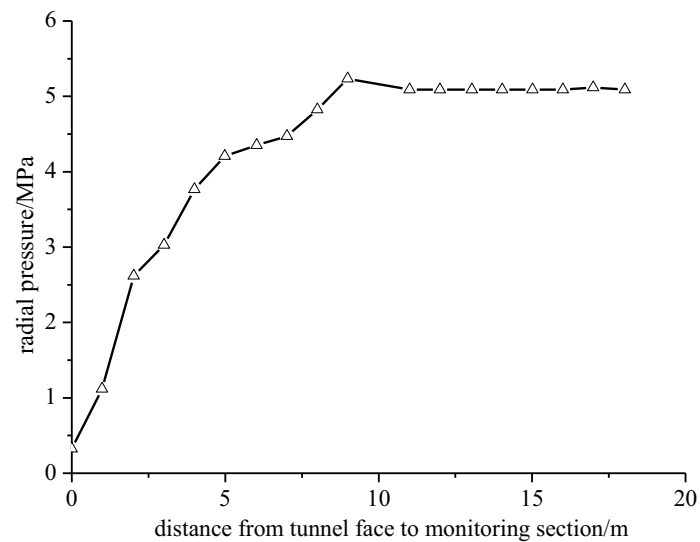

(d) Radial pressure curve of tunnel floor

Fig. 14. surrounding rock pressure curve

It is seen from the chart that excavation influenced the surrounding rock pressure within the range of 1 time the tunnel diameter. Vertical pressure in front of the working face started to release at a half the distance of the tunnel diameter, which was highly influenced by excavation. Vertical pressure release rate reaches the maximum, which was about $0.3 \mathrm{MPa} / \mathrm{m}$ at the place where the working face was 3 to 5 meters away from the monitoring points. This can be considered the main relaxation process of rock in front of the working face. Then, the vertical pressure continued to reduce and the pressure became 0MPa when the final excavation was finished. For other results of the detailed analysis of the measuring point, please refer to the literature [20]. 


\section{CONCLUSIONS AND RECOMMENDATIONS}

(1) Because of the complexity of the model test in the tunnel construction process, stress, displacement and stress monitoring is established in the integration of multivariate information monitoring system, and the model test system was applied to the actual tunnel construction process to realize the real-time and accurate dynamic model test of multivariate information acquisition.

(2) Independent research and development of mechanical and grating type micro-precision displacement meter test systems show the measurement accuracy can reach $1 \mu \mathrm{m}$ and it can verify the exact amount of the test process of internal displacement of surrounding rock largely unaffected by the external environment and it can be widely used in underground model test projects.

(3) Fiber grating testing technology, when compared to traditional measurement technology, has good storage stability and high sensitivity. The results show that fiber optic sensing technology is able to accurately measure the amount of displacement and stress distribution in the tunnel during the test, but it has high cost, is easily beakable and difficult to reuse the features. However, with continuous development and improvement of the technology, it will have high application value.

ACKNOWLEDGMENTS: This study was supported by National Natural Science Fund Project (Grant No. 51408054), the Ministry of Education Doctoral Fund (20130205110004), the Fundamental Research Funds for the Central Universities (Grant No. 310821163115 and 310828161004), the Research Project of Shannxi Provincial Transport Department (Grant No. 13$14 \mathrm{~K})$. 


\section{REFERENCES}

1. SHEN Tai, "Development of geomechanic model experiment techniques", Journal of Yangtze River Scientific Research Institute, 185(5): 32-36, 2001.

2. Chen Anmin, Gu Jincai, Shen Jun, et al., "Application study on the geomechanical model experiment techniques", Chinese Journal of Rock Mechanics and Engineering, 23(22): 3785-3789, 2004.

3. Li Xiaohong, Lu Zhengyi, Kang Yong, "Experimental rock mechanics simulation techniques", Beijing: Science Press, 2007.

4. LIU Qin, "Study on Large Deformation Mechanism and Control Measures of Soft Fractured Rock and Its Application for Carbonaceous Shale Tunnel”, PHD thesis, Shandong University, Jinan, 2011.

5. CHEN Xu-guang, ZHANG Qiang-yong, DUAN Kang, et al, "Research on application of optical sensor-based measuring method to model test”, Rock and Soil Mechanics, 33(5): 1409-1415, 2012.

6. LIU De-jun, ZHANG Qiang-yong, CHEN Xu-guang, et al., "Study on Deformation Measurement in Surrounding Rock Failure Model Test of Deep Roadway", JOURNAL OF SICHUAN UNIVERSITY (ENGINEERING SCIENCE EDITION), 42(4): 71-77, 2010.

7. Lei Mingfeng, Pen Limin, Shi Chenghua, et al., "Model research on failure mechanism and lining stress characteristics of shallow buried tunnel under unsymmetrical pressure", Journal of Central South University(Science and Technology), 44(8), 3316-3325, 2013.

8. Duan Hongfei, Jiang Zhenquan, Zhu Shuyun, ea al, "Centrifuge model tests on rock brusting induced by great depth highly stressed roof strata of weak structural plane", Journal of Central South University (Science and Technology), 42(9): 2774-2782, 2011.

9. Wang Aimin, Tao Jikun, Li Zhongkui, "The design and application of micro-precision displacement meter in three-dimensional model test”, 19(5): 21-26, 2002.

10. Jiang Hong, "PPP-BOTDA distributed fiber optic sensing techniques and its application to pile tests", Rock and Soil Mechanics, 32(10): 3190-3196, 2010.

11. Q.B. Zhang, L. He, W.S. Zhu, "Displacement measurement techniques and numerical verification in 3D geomechanical model tests of an underground cavern group", Tunnelling and Underground Space Technology, 56: 54-64, 2016.

12. Mingfeng Lei, Limin Peng, Chenghua Shi, "Model test to investigate the failure mechanisms and lining stress characteristics of shallow buried tunnels under unsymmetrical loading", Tunnelling and Underground Space Technology, 46: 64-75, 2015.

13. Zhang Wei, Shi Bin, Suo Wenbin, et al., "Monitoring and application of distributed optical fiber sensors in transient temperature field of frozen soil", Chinese Journal of Geotechnical Engineering, 29(5): 723-728, 2007.

14. Piao Chun-de, Shi Bin, Wei Guang-qing, et al., "Application of distributed fiber optic sensing techniques in bored pile detection", Chinese Journal of Geotechnical Engineering, 30(7): 976-981, 2008.

15. Li Ke, Shi Bin, Tang Chao-sheng. "Feasibility research on soil deformation monitoring with distributed optical fiber sensing technique", Rock and Soil Mechanics, 31(6): 1781-1785, 2010.

16. Zhang Qian-bing, ZHU Wei-shen, LI Yong, et al., "Design of mini multipoint extensometer in geomechanical model test of cavern group and its application”, Rock and Soil Mechanics, 33(2): 623-628, 2011.

17. Zhang Qiangyong, Li Shucai, Li Yong. "3D geomechanical model test research on stability and supporting for surrounding rock mass of a large- scale diversion tunnel", Chinese Journal of Rock Mechanics and Engineering (S2): 4051-4069, 2007.

18. Gao Yang, Zhang Qingsong, Li Shucai, et al., "An experiment of temperature field of rock mass near waterbearing structure during roadway excavation”, Journal of Central South University(Science and Technology), 45(2): 550-556, 2014.

19. Zhang Qiang-yong, Li Shu-cail, Guo Xiao-hong, et al., "Research and development of new typed cementitious geotechnical similar material for iron crystal sand and its application", rock and soil mechanics, 29(8): 2126$2130,2008$.

20. Zhao Yan, "Research of The Load Releasing Law During the Construction Process of Large Section Tunnel", MASTER's thesis, Shandong University, Jinan, 2011. 


\section{LIST OF FIGURES AND TABLES:}

Fig. 1. Monitor section position sketch

Rys. 1. Szkic pozycji sekcji monitorowania

Fig. 2. Monitoring points position sketch

Rys. 2. Szkic pozycji punktów monitorowania

Fig. 3. FBG monitoring system diagram

Rys. 3. Schemat systemu monitorowania FBG

Fig. 4. FBG monitoring components

Rys. 4. Elementy monitorowania FBG

Fig. 5. FBG monitoring system

Rys. 5. System monitorowania FBG

Fig. 6. Micro-multi-point displacement measurement points

Rys. 6. Punkty pomiaru przemieszczenia mikrowielopunktowego

Fig. 7. Schematic diagram for working principle of mechanical multi-point extensometer

Rys. 7. Schemat strukturalny zasady działania mechanicznego tensometru wielopunktowego

Fig. 8. Mechanical micro-multi-point displacement meter after installation

Rys. 8. Mechaniczny miernik przemieszczenia mikrowielopunktowego

Fig. 9. Grating multi-point displacement meter data acquisition system

Rys. 9. Zezwolenie systemowi pozyskiwania danych na dostęp do miernika przemieszczenia wielopunktowego

Fig. 10. Embedment procedure of micro earth pressure cell

Rys. 10. Procedura posadowienia mikrokomórki parcia gruntu

Fig. 11. Strain and pressure test system

Rys. 11. Układ badania rozciągania i ciśnienia

Fig. 12. Antecedent displacement variation of tunnel face

Rys. 12. Zmiana poprzedniego przemieszczenia przodka tunelowego

Fig. 13. Final radial displacement distribution of the monitoring sections

Rys. 13. Ostateczny rozkład przemieszczenia promieniowego sekcji monitorowania

Fig. 14. surrounding rock pressure curve

Rys. 14. krzywa ciśnienia otaczającego kamienia

Tab 1. The performance parameters of FBG sensors

Tab. 1. Parametry wydajności czujników FBG

Tab 2. Final peripheral displacement of the main monitoring sections

Tab. 2. Ostateczny rozkład przemieszczenia peryferycznego głównych sekcji monitorowania 


\section{ZASTOSOWANIE SYSTEMU DYNAMICZNEGO MONITOROWANIA WIELOCZYNNIKOWEJ INFORMACJI PODCZAS BADANIA MODELU PROCESU BUDOWY TUNELU}

Slowa kluczowe: budowa tunelu, informacja wieloczynnikowa, monitorowanie dynamiczne, badanie modelu

\section{STRESZCZENIE:}

Niniejsza praca omawia system dynamicznego monitorowania wieloczynnikowej informacji podczas badania modelu procesu budowy tunelu.

Geometryczna metoda badania modelu jest skuteczną metodą badania poważnych problemów geotechnicznych, które wiążą się ze stosowaniem podobnych materiałów w pomieszczeniu, tworzeniem podobnych modeli na podstawie podobnych zasad oraz opierają się na obserwacji naprężeń, odkształceń i przemieszczeń wielowymiarowej informacji, w celu zrozumienia zjawiska mechanicznego i prawa stanu naprężeń i przemieszczeń na prototypie, aby osiągnąć cel realizacji geotechnicznego projektowania i budowy. Z uwagi na praktyczne, zaawansowane przemieszczenie w przedniej części tunelu oraz przemieszczenie samej powierzchni tunelu, pomiary są trudne do przeprowadzenia za pośrednictwem monitorowania. Możemy prowadzić skuteczną analizę i dyskusję dotyczącą słabej/ uszkodzonej skały otaczającej przy użyciu podobnej geometrycznej metody badania modelu. Jednakże, badania modelu zależą od wielu czynników w rzeczywistym procesie zastosowania, przez co trudno jest osiągnąć pożądany efekt. Wśród nich, technologia pozyskiwania licznych informacji na temat dynamicznego monitorowania procesu badania stała się ważnym czynnikiem, ograniczającym rozwój geometrycznej metody badań modelu. Jak wiemy, mnogość informacji geometrycznej na temat metody badań modelu obejmuje napięcie, naprężenie, ciśnienie, przemieszczenie, itp. Mnogość informacji w procesie budowy tunelu, takich jak dynamiczne monitorowanie pierwszego przemieszczenia, przemieszczenie i tylne przemieszczenie powierzchni tunelu, jest rzadko analizowana. Jednakże, pomyślne zdobycie licznych informacji podczas budowy tunelu jest kluczem do sukcesu w badaniu modelu. Dlatego też, w celu zbadania systemu monitorowania wielu informacji $\mathrm{w}$ procesie budowy tunelu, należy uchwycić stan przekształcenia i naprężenia, jak również zwiększyć dokładność pomiarów i nie ma wątpliwości co do pełnego wykorzystania zalet technologii badań modelu. Na podstawie techniki monitorowania światłowodu, różnorodny zbiór informacji dla systemu monitorowania jest tworzony jako rdzeń systemu dynamicznego monitorowania światłowodu w czasie rzeczywistym. W połączeniu z wysokoprecyzyjnym mechanicznym i mikroprzemieszczającym miernikiem o typie kraty i innymi środkami, zgodnie z wymogami pomiarów badania modelu, system monitorowania licznych informacji został opracowany i skutecznie wykorzystany w procesie budowy tunelu. Wyniki badania modelu pokazują, że system może być stosowany do monitorowania procesu budowy tunelu, a ponadto jest zdolny do wychwytywania drobnych zmian i wartości fluktuacji komunikatów wielojednostkowych, jak również do tworzenia podwaliny dla powodzenia badania modelu.

Badanie to opierało się na masowym odkształceniu typowo uszkodzonej skały otaczającej w tunelu górskim Gui-Guang Line TianPing. Odcinek DK372+335 DK372+435 został wybrany do stymulacji badania modelu mechaniki geologicznej. Średnia głębokość odcinka wyniosła 380 metrów. Symulacyjna wielkość prototypu wyniosła: szerokość (prostopadle do kierunku osi tunelu, czyli oś Y) x wysokość (wzdłuż kierunku wzniesienia, czyli oś Y) x grubość (równolegle do osi tunelu, czyli oś Z) = $120 \mathrm{~m}$ x $120 \mathrm{mx}$ x $100 \mathrm{~m}$. Stosunek geometryczny o podobnej wielkości badania modelu geologicznego wynosi 1:50, zgodnie z zarysem pracy. Dzięki temu uzyskano symulacyjną wielkość modelu: szerokość (prostopadle do kierunku osi tunelu, czyli oś X) x wysokość (wzdłuż kierunku wzniesienia, czyli oś Y) x grubość (równolegle do osi tunelu, czyli oś Z) $=2.4 \mathrm{~m} \mathrm{x} \mathrm{2,4} \mathrm{m} \mathrm{x} 2 \mathrm{~m}$. W oparciu o rzeczywistą sytuację metody budowy, to badanie modelu obejmowało metody wykopu na dwóch etapach oraz wykopu w przeciwnym kierunku tunelu. Wyjaśnia to prawo transformacji stanu naprężeń wewnętrznych i przemieszczeń w otaczającej skale, jak również zmianę w procesie budowy poprzez punkt monitorowania przemieszczeń, naprężeń i odkształceń. Na podstawie wymagań pomiarowych dotyczących badania modelu, w połączeniu z technologią czujników FBG (czujników światłowodowych) i tradycyjnymi metodami pomiarowymi, rozwijany jest system monitorowania FBR, mikro-wielopunktowy system badania przemieszczenia, system badania piezorezystancyjnego oraz system monitorowania ciśnienia skały otaczającej. Dzięki zastosowaniu systemów do badania modelu w procesie budowy tunelu, uzyskano przemieszczenie w ustawach dotyczących powierzchni tunelu, prawach dotyczących rozkładu promieniowych przemieszczeń i praw dotyczących ciśnienia skał otaczających.

Niezależne badania i rozwój systemów badań miernika mikro-precyzyjnych przemieszczeń typu kraty i typu mechanicznego pokazują, że dokładność pomiaru może osiągnąć wartość $1 \mu \mathrm{m}$ i może weryfikować dokładną ilość procesów badań wewnętrznego przemieszczenia skały otaczającej, w dużej mierze niezależnie od środowiska zewnętrznego, a także może być szeroko stosowana w podziemnych projektach badań modelu. Technologia światłowodowych czujników, w porównaniu z tradycyjną technologią pomiarową, charakteryzuje się dobrą stabilnością przechowywania i wysoką czułością. Wyniki pokazują, że technologia wykrywania czujników światłowodowych posiada 
możliwość dokonywania dokładnych pomiarów ilości przemieszczeń i rozkładu naprężeń w tunelu podczas badań, lecz niesie za sobą wysokie koszty, łatwą zniszczalność i trudność ponownego wykorzystania możliwości. Jednakże, dzięki stałemu rozwojowi i doskonaleniu technologii, będzie ona posiadać wiele zastosowań.

Wyniki badań pokazują, że system monitorowania wieloczynnikowych informacji charakteryzuje się wysoką precyzją, stabilnością i silną zdolnością przeciwdziałania zakłóceniom. Określa on solidne podstawy monitorowania danych w czasie rzeczywistym, w ramach badania modelu procesu budowy tunelu. 